\title{
Age, Growth, Reproduction and Fecundity of Roach Rutilus rutilus from Volvi Lake, Northern Greece
}

\author{
Stavroula Kyritsi ${ }^{1, *} \mathbb{D}$, Antonis K. Kokkinakis ${ }^{2}$
}

\begin{abstract}
${ }^{1}$ Alexander Technological Educational Institute of Thessaloniki, School of Agricultural Technology, Food Technology and Nutrition, Department of Agricultural Technology, Division of Animal Production, Box 141, 57400 Thessaloniki, Greece

${ }^{2}$ Aristotle University of Thessaloniki, Faculty of Forestry and Natural Environment, Laboratory of Wild Life and Freshwater Fisheries, Box 241, 54124 Thessaloniki, Greece.
\end{abstract}

\section{Article History}

Received 12 Jun 2018

Accepted 11 February 2019

First Online 07 July 2020

\section{Corresponding Author}

Tel.: +302310013567

E-mail: stakir@gmail.com

\section{Keywords}

Life history traits

Freshwater

Greece

Eastern Mediterranean

\begin{abstract}
The roach, Rutilus rutilus, is a Cyprinid which is widely distributed throughout freshwater systems in Europe. It is one of the most abundant and important commercial fish species in Greece. Age, growth, reproduction and fecundity of roach were studied in Lake Volvi from 1997-1998 females had higher growth in length $\left(L_{\infty}=277.18 \mathrm{~mm}, k=0.097\right)$ than adult males $\left(L_{\infty}=185.60 \mathrm{~mm}, \mathrm{k}=0.148\right)$. All males older than one year and larger than $70 \mathrm{~mm}$, and all females older than two years and larger than $80 \mathrm{~mm}$ were sexually mature. The breeding period spanned from the end of March till mid April. Fecundity ranged from 2,036 to 31,653 eggs (mean 8,102 eggs) and relative fecundity from 76.06 to $333.94 \mathrm{eggs} / \mathrm{g}$ (mean $186.78 \mathrm{eggs} / \mathrm{g}$ ). Diameter of eggs were $1.3 \pm 0.07 \mathrm{~mm}$ and weighted $0.0011 \pm 0.0002 \mathrm{~g}$. The weight of eggs were independent of length and age of individuals $(P>0.05)$, however, there was a significant relationship between weight and egg diameter $(P<0.05)$. Absolute fecundity depended on length, weight and age of the females. The relationship between absolute fecundity and length were less obvious in the case of relative fecundity and egg size. Estimated growth was at the lower end when compared with other studies conducted elsewhere.
\end{abstract}

\section{Introduction}

Roach, Rutilus rutilus (Linnaeus, 1758), is natural population throughout western and northern Europe (up to $69^{\circ} \mathrm{N}$ in Scandinavia and $56^{\circ} \mathrm{N}$ in Scotland), southern Europe to the north of the Pyrenees, and are found as far eastwards and southwards as the Ural Mountains, the Balkans and the catchments that drain into the Aegean, Black and Caspian seas. In Europe locally introduced in Spain, northeastern Italy and in Cyprus (Kottelat \& Freyhof, 2007). In Australia was introduced from Europe in the 19th century (Stoessel, 2014). In Greece it is present from Thessalian Pinios to Evros river drainages. Also found in Kastoria, Doirani, Volvi and Vegoritis lakes. This fish inhabits a variety of habitats (nutrient-rich lakes, large- to medium-sized rivers, reservoirs and backwaters), but in Greece it is mainly found in lowland areas. (Barbieri et al, 2015). In the Balkan Peninsula, age and growth of roach have been studied in depth (e.g. Zivkov \& Raikova-Petrova, 2001; Staras, Cernisencu, \& Navodaru, 1995).

In freshwaters of Greece, roach is an abundant, commercial native species, (i.e., Economidis \& Banarescu, 1991; Economou, Giakoumi, Vardakas, Barbieri, Stoumboudi, \& Zogaris, 2007; Bobori, Moutopoulos, Bekri, Salvarina, \& Munoz, 2010), however, few studies have accessed age and growth of individuals in populations. In Lake Volvi, only two studies for roach have been conducted in 35 years (i.e., Papageorgiou, 1979; Bobori, Kanakis, Petriki, \& Tsikliras, 2017). Lake Volvi (Northern Greece, Figure 1) is the second largest natural lake in Greece, and together with the adjacent Lake Koronia belongs to the National Wetland Park. Wetland Parks have international 


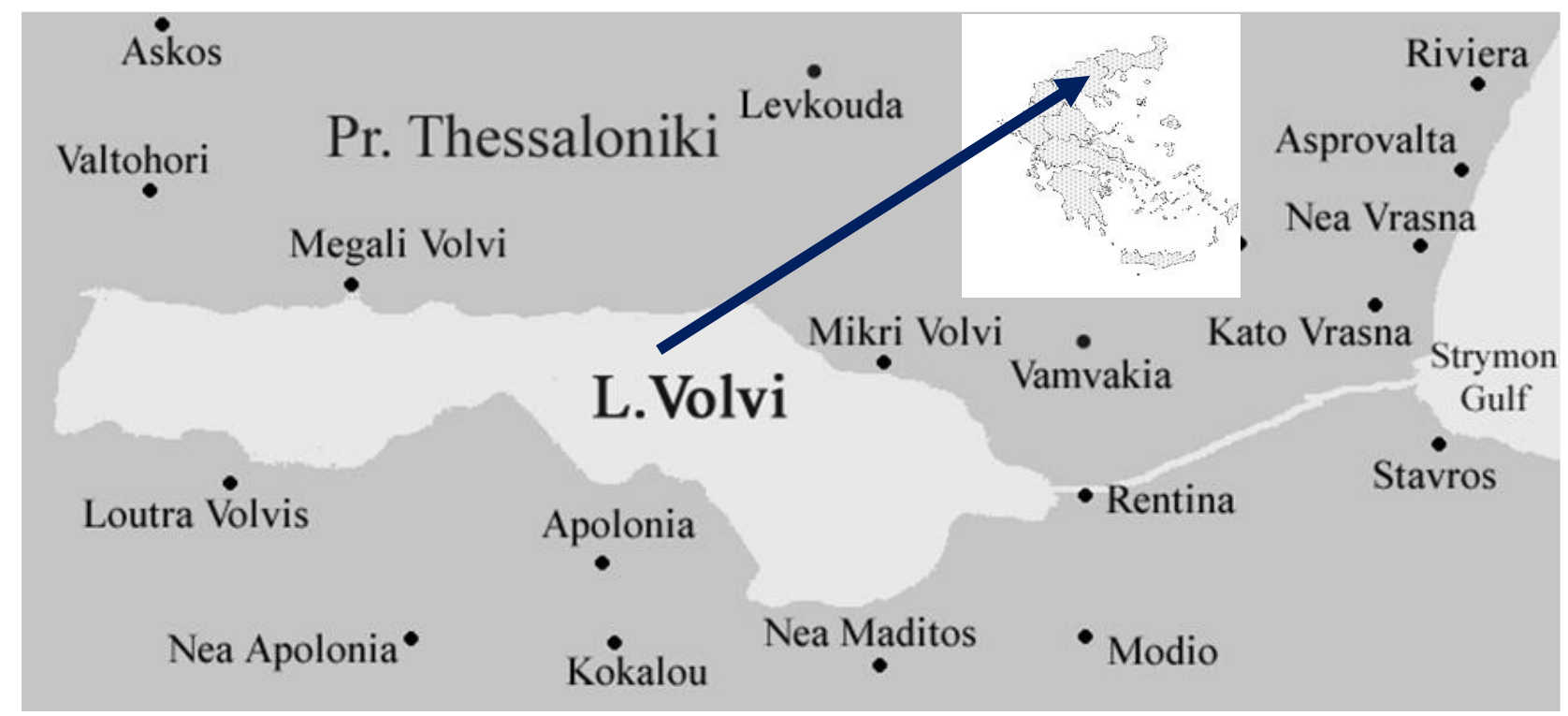

Figure 1. Map of the area in which the study was conducted.

significance (Ramsar Convention) and are included in the NATURA 2000 network under the 2009/147/EEC and 92/43/EC Directives. Both lakes are also included in the Barcelona Convention for the Protection of the Mediterranean.

The aim of the present study was to investigate the life-history of the roach population in the lake Volvi by assessing the: (a) age-growth relationship, (b) annual reproductive progression, (c) fecundity (d) size of eggs, and (e) a comparison was then undertaken of parameter estimates derived from studies undertaken elsewhere. Reliable estimation of age-growth parameters can be incorporated for the development of ecosystem models for the conservation and management of lakes in a multi-species context. Fecundity and relative issues, such as the number, diameter and weight of the eggs, are a part of the estimation for the reproduction of each fish species.

\section{Materials and Methods}

Roach were collected monthly from November 1997 to November 1998 from lake Volvi using six gill nets, with stretched mesh sizes of 16, 20, 24, 28, 34 and $40 \mathrm{~mm}$. In March 1999, supplementary sampling was done (i.e., 'once only') using 16 gill nets with stretched mesh sizes of $10,12,15,18,22,24,26,28,32,34,36$, $38,40,45,50$ and $60 \mathrm{~mm}$. In total, 3,384 fish samples were collected. From those 2,499 were collected by monthly samplings and 885 from "once only" sampling. Individuals captured were recorded per mesh size and placed in a solution of formaldehyde (10\%) until later analyses. For each specimen were measured the fork length (FL) to the nearest $1 \mathrm{~mm}$, total weight (TW), somatic (eviscerated) weight "net" (NW) to the nearest $0.1 \mathrm{~g}$ and gonad weight (GW) to the nearest $0.01 \mathrm{~g}$.

Scales from 885 individuals were used for age and growth studies. For age determination, scales were taken between the lateral line and dorsal fin (Bagenal \&
Tesch, 1978), placed in a plate with hot water where a drop of $\mathrm{NaOH}(8 \%)$, dried and mounted between microscope slides. Each scale was read by two different readers. There was no significant difference between readers based on $t$-test $(t<0.05)$. The readers using a special projector (Projecting 4002-H), featured a magnified screen and a graduated scale. Age of the roach was determined from the number of scale annuli (Bagenal \& Tesch, 1978). The annulus is interpreted according to Bagenal and Tesch (1978).

The relation between the fork length $(\mathrm{FL})$ and scale radius was estimated for males and females by sex and for both sexes combined. Analysis of covariance (ANCOVA) was used for comparison of the above relations derived for male and female roach.

The annual back calculation length growth relationship was estimated using the modified relation proposed by Monastyrsky (Bagenal \& Tesch, 1978) using data derived from specimens captured during the "once only" sampling event: $\log I_{n}=\log I+b\left(\log S_{n}-\log S\right)$ where, In, is the 'back calculated' length in the age $n, I$, is the fork length of the fish at capture, $S_{n}$, radius of the scale from the center till the ring $n, S$, radius of the scale.

Von Bertalanffy equation was used for estimating growth parameters: $\mathrm{Lt}=\mathrm{L} \infty\left[1-\mathrm{e}^{(-\mathrm{k}(\mathrm{t}-\mathrm{t} 0)}\right]$. Von Bertalanffy parameters $L \infty, k$ and to were estimated using the Ford -Walford graph.

The annual back growth per weight was estimated by using the modified equation of Von Bertalanffy (Hilborn \& Walters, 1992): $W(t)=W_{\infty}\left(1-e^{(-k(t-t o)) b}\right)$, where $\mathrm{W}_{\infty}=\mathrm{a} \cdot \mathrm{L}_{\infty}^{\mathrm{b}}$. Data were derived from previous results/estimations. The spawning period and the gonadosomatic index (GSI) were determined from monthly samples estimated. GSI determined as per Wootton (1992).

From the 'once only' sampling 481 female specimens were identified as "mature" (stage V-VI), according to the Kesteven scale which has been described by Holden and Raitt (1974) and Lagler (1978). 
Absolute fecundity has been considered as the number of ripening eggs in the female prior to spawning (Bagenal \& Braum, 1978). It was estimated from 153 specimens identified as being at stage V. Gilson's fluid was used for the preservation of the ovaries, and the gravimetric sub-sampling method (Bagenal, 1978) was used to estimate the absolute fecundity. The relation of absolute fecundity " $F$ " with length, weight (total and net weights) and age was estimated as per the formula given by Bagenal equation (1978) $\mathrm{F}=\mathrm{a} \cdot \mathrm{x}^{\mathrm{b}}$, where, $\mathrm{a}$ and $\mathrm{b}$ are constants, $x$ was length, (total - net) weight and age. The theoretical value of the absolute fecundity was estimated from the previous equation, where $x$ is the length estimated from the Von Bertalanffy equation.

Diameters of eggs were measured under a stereomicroscope with an ocular micrometer. Two samples of 400 eggs were taken from each gonad. The average of these diameters was considered to be the mean egg size. The relationship between the egg diameter and egg weight with fork length, weight (totalnet) and age was examined. Relative fecundity was obtained by dividing absolute fecundity with total weight (TW) of fish.

\section{Results}

\section{Growth}

In total, 3,384 fish samples were collected from which 2,499 were collected monthly and 885 "once only". Figure $2 a$ demonstrates the average distance between the last annuli and the outer scale. As we can notice the distance was found to be lower at late April.
Figure $2 b$ shows that this distance was formed between February and July with the ring to be present in $85 \%$ of the samples between April and May. The relation between length and scale radius was significantly correlated with sex $(P<0.05$, Table 1 , Table 2$)$. Males were on average larger $(74 \mathrm{~mm})$ than females $(69 \mathrm{~mm})$ in the first year, however, the growth of females was higher in all years following (Figure $3 a, b)$. Equivalent von Bertalanffy growth parameters were $L \infty=185.6 \mathrm{~mm}$, $k=0.148$ and $t_{o}=-2.33$ for males $(n=404), L \infty=277.2 \mathrm{~mm}$, $k=0.097$ and $t_{o}=-1.85$ for females $(n=481)$ roach (Figure 4a). A significant difference existed between the mean lengths-at age of the sexes, with females on average being larger than males (ANCOVA, $P<0.05$ ). Similarly, growth weight parameters were $W \infty=120.1 \mathrm{~g}$ for males $(n=404), W \infty=508.6 \mathrm{~g}$ for females $(n=481)$ roach (Figure $4 b)$. The most rapid growth and growth weight of female compared to male individuals occurred up to the age of $2+$ years.

\section{Reproduction}

Assessment of the main spawning period of roach in Lake Volvi was based on the GSI. In both sexes the annual values of the GSI index were higher toward the end of winter and early spring (Figure 5), which declined rapidly in April. Over summer, GSI reached its lowest value; male 0.33 ( $S D=0.15)$ female 1.09 ( $S D=1.83$ ). During December and January GSI of males increased in weight to $76 \%$ of the final weight. In females, GSI attained its highest value in November $(23.8 \%$ of final weight) and just prior to the suspected spawning period in March (represented $21 \%$ of the final weight).
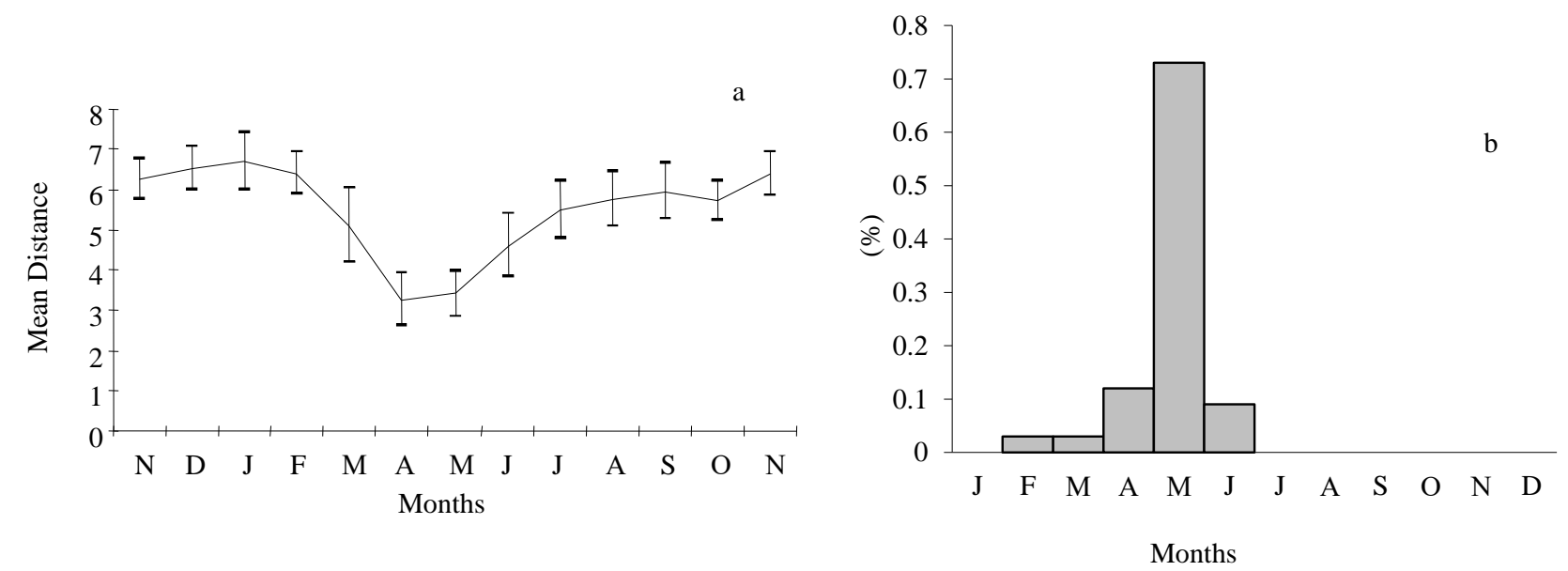

Figure 2. a) Mean monthly distance after the last check of annual ring on the scales of roach in lake Volvi (95\% confidence intervals), b) Monthly \% of roach that they have just formatted new annual ring ( $N=2,499)$.

Table 1. Relation between fork length $(L, \mathrm{~mm})$ and radius $(\mathrm{R})$ of roach (Rutilus rutilus) in Lake Volvi

\begin{tabular}{lccr}
\hline Sex & Linear Equation & $\mathrm{R}^{2}$ & $\mathrm{~N}$ \\
\hline Male \& Female & $\mathrm{L}=32.817+1.53 \mathrm{R}$ & 0.863 & 885 \\
Male & $\mathrm{L}=37.306+1.44 \mathrm{R}$ & 0.815 & 404 \\
Female & $\mathrm{L}=30.847+1.57 \mathrm{R}$ & 0.884 & 481 \\
\hline
\end{tabular}


Table 2. "Back calculated" lengths $(\mathrm{mm})$ of roach in Lake Volvi (male \& female) Where, $\mathrm{Lt}=$ is the 'back calculated' length in the age $t(t=1,2 . .8)$

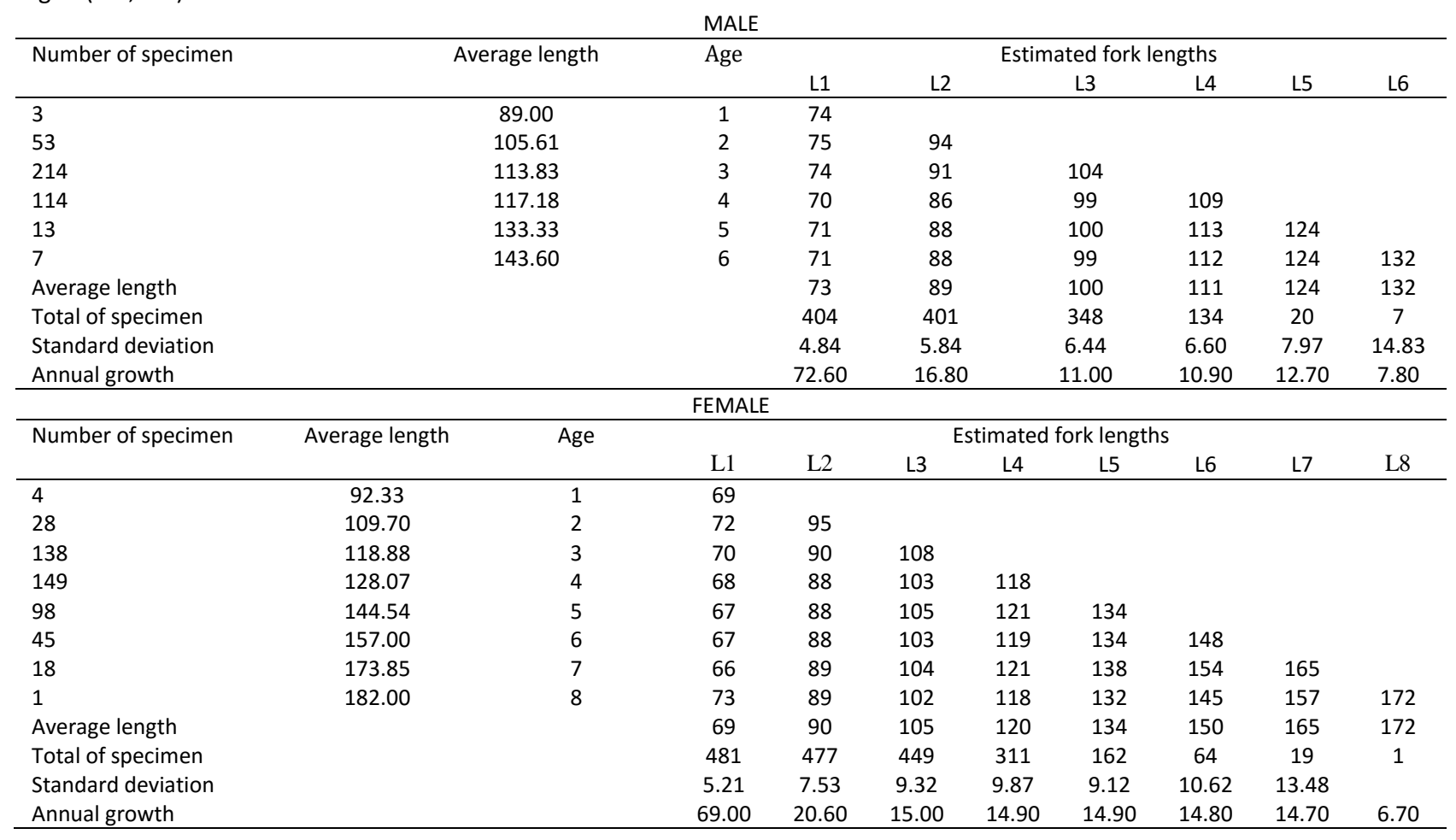
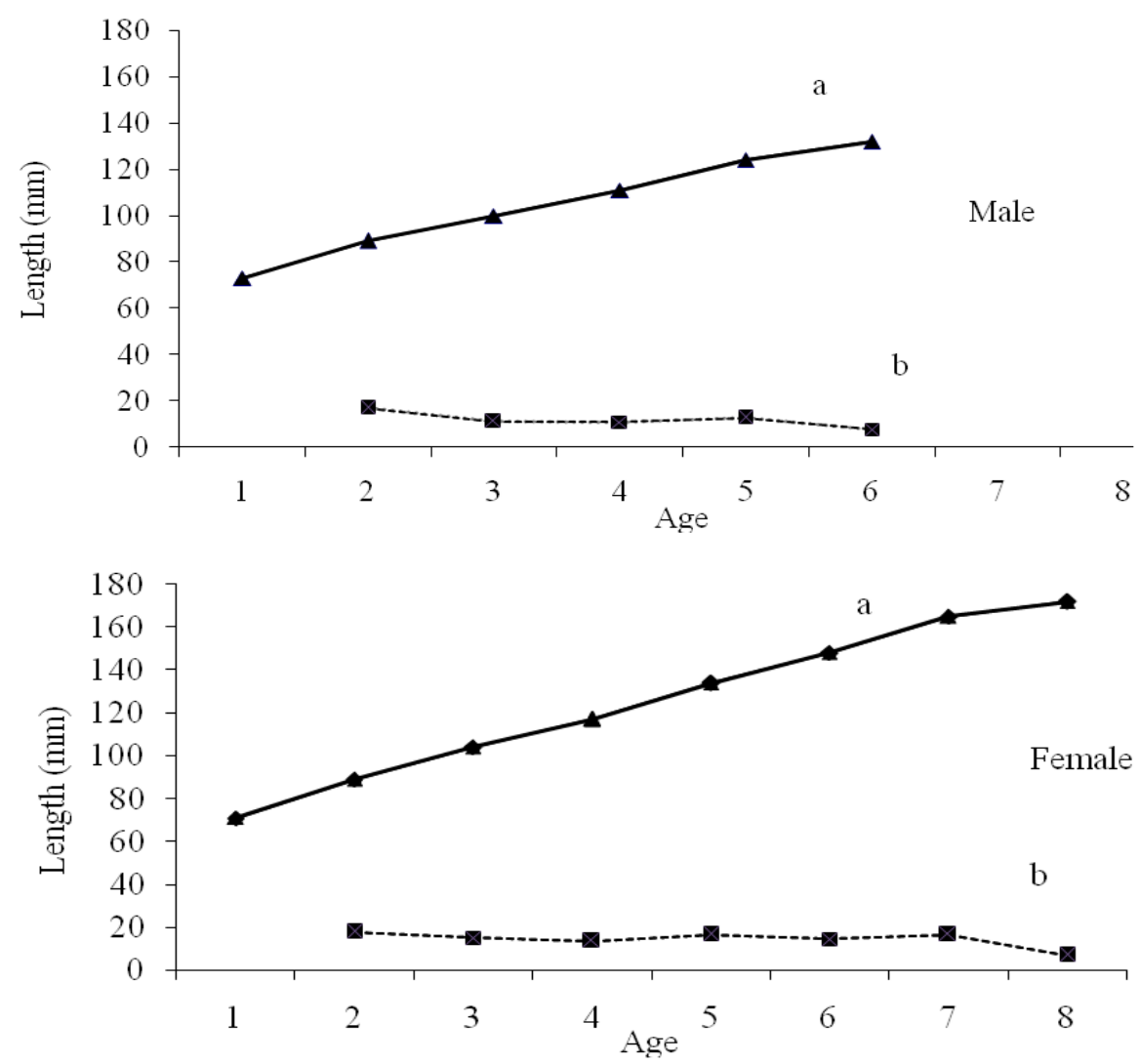

Figure 3. The mean 'back calculated' lengths (a) of males $(\mathrm{N}=404)$ and females $(\mathrm{N}=481)$ roach in Lake Volvi at each age group and (b) the annual rate of growth. 

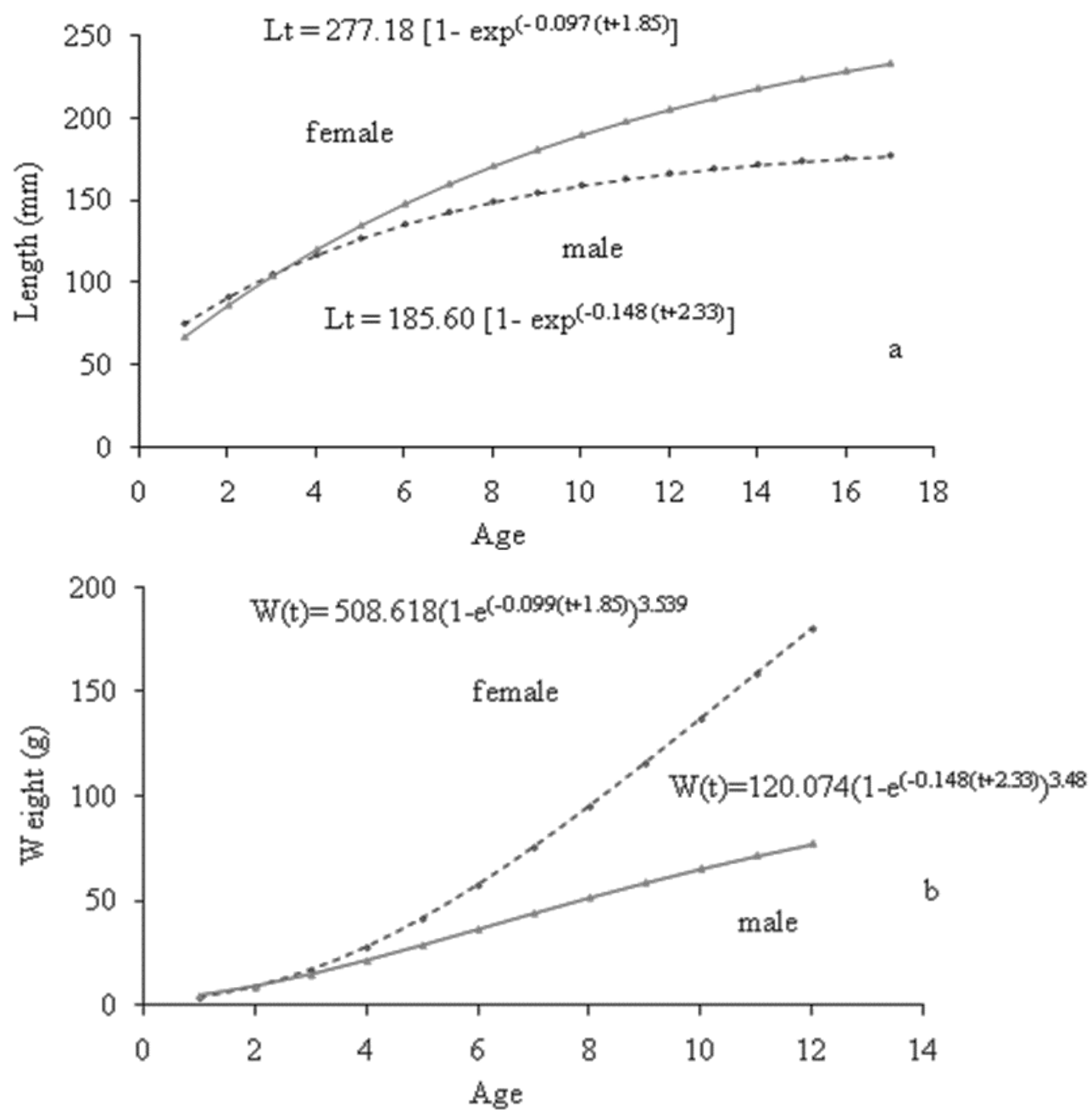

Figure 4 a) Growth of male and female roach with Von Bertalanffy method. b) Back calculated growth weight curve roach with age.

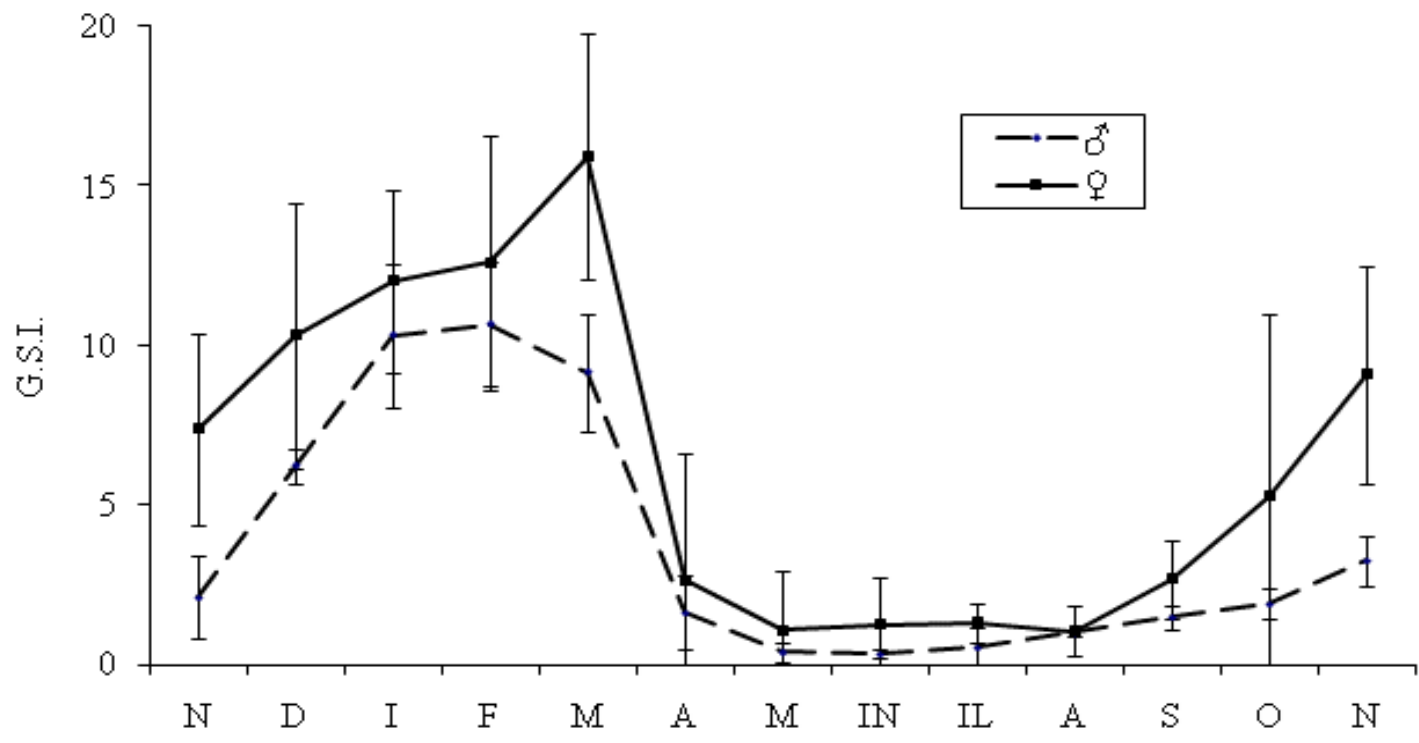

Figure 5. Mean values of the gonadosomatic index with $95 \%$ significance level per sex $(N=2,499)$ 
In 'once only' sampling we noticed that males greater than $70 \mathrm{~mm}$ and females greater than $80 \mathrm{~mm}$ had achieved stage V-VI. Some of males attained the first maturity at the age of $1+$ year, with all the males presented to be mature at the age of $2+$. In contrary, some females started to be mature at the age of $2+$ and all them older were matured at the age of $3+$ years.

\section{Fecundity and Egg Size}

Fecundity of roach in Lake Volvi ranged from 2,036 to 31,653 with a mean value of 8,102 . Absolute fecundity increased significantly $(P<0.05)$ with increasing length, weight (total and "net") and age. Table 3 shows the average number of eggs of roach in lake Volvi per age class of the spawners. The number of absolute fecundity per length and "net weight" of the female roach in Lake Volvi in each age class is presented in Table 4.
The relation between absolute fecundity and fork length, total weight, "net weight" and age is presented in Table 5. Also Figure 6a shows the absolute fecundity and its theoretical value. Mean fecundity exhibited a declining trend from the theoretical value, which up to the age of $5+$ approached the lowest limit of the confidence intervals of fecundity. The relation of absolute fecundity with the relative fecundity and body length of the spawners are shown in Table 6. Average relative fecundity (RF) was 186.78 eggs/g (range: 76.06 to 333.94) with RF values exhibiting no significant $(P>0.05)$ trend with length, weight (total- net) and age.

Eggs were $1.3 \pm 0.07 \mathrm{~mm}$ in diameter (range: $1.1 \mathrm{~mm}$ to $1.4 \mathrm{~mm}$ ) and weighted $0.0011 \pm 0.0002 \mathrm{~g}$ (range: $0.0007 \mathrm{~g}$ to $0.0015 \mathrm{~g})$. The weight of eggs were independent of length and age of individuals $(P>0.05)$, however, there was a significant relationship between weight and egg diameter $(P<0.05)$ (Table 7).

Table 3. Average number of eggs of roach (Rutilus rutilus) in Lake Volvi per age class of the spawners

\begin{tabular}{lccccc}
\hline Age & $\begin{array}{c}\text { Average } \\
\text { value }\end{array}$ & SD & SE & N & $\begin{array}{c}\text { Confidence } \\
\text { intervals 95\% }\end{array}$ \\
\hline 3 & $4,284.94$ & 1.565 & 368.94 & 18 & $3,916.00$ \\
4 & $5,033.09$ & 2.372 & 361.74 & 43 & $4,671.36$ \\
5 & $8,077.58$ & 2.504 & 317.99 & 62 & $9,704.45$ \\
6 & $12,996.40$ & 4.167 & 817.27 & 26 & $1,759.59$ \\
7 & $21,231.39$ & 6.453 & $3,226.26$ & 4 & $12,179.13$ \\
\hline
\end{tabular}

Table 4. Number of absolute fecundity per length and net weight of the female roach (Rutilus rutilus) in Lake Volvi in each age class.

\begin{tabular}{|c|c|c|c|c|c|c|c|c|c|c|c|c|}
\hline Age & & & & & & Length $(\mathrm{mm}$ & & & & & & $\mathrm{N}$ \\
\hline & $100-109$ & $110-119$ & $120-129$ & $130-139$ & $140-149$ & 150-159 & $160-169$ & $170-179$ & $180-189$ & 190-199 & $200-209$ & \\
\hline $3^{+}$ & 2789 & 4829 & & & & & & & & & & 18 \\
\hline $4^{+}$ & 4039 & 3783 & 5380 & 8755 & 9714 & & & & & & & 43 \\
\hline $5^{+}$ & & 3892 & 5058 & 7180 & 9402 & 10185 & 12625 & & & & & 62 \\
\hline $6^{+}$ & & & & 8449 & 10370 & 11079 & 16419 & & 22057 & & & 26 \\
\hline $7^{+}$ & & & & & & & & 13962 & 23450 & 26282 & 31653 & 4 \\
\hline $\mathrm{N}$ & 6 & 39 & 19 & 23 & 28 & 23 & 10 & 1 & 2 & 1 & 1 & 153 \\
\hline Age & & & & & & Jet weight & & & & & & $\mathrm{N}$ \\
\hline & $10-19$ & $20-29$ & 30-39 & $40-49$ & $50-59$ & $60-69$ & $70-79$ & $80-89$ & $90-100$ & & & \\
\hline $3^{+}$ & 4285 & & & & & & & & & & & 18 \\
\hline $4^{+}$ & 4083 & 5295 & 9564 & 10574 & & & & & & & & 43 \\
\hline $5^{+}$ & 4967 & 6341 & 8608 & 10410 & 10043 & & & & & & & 62 \\
\hline $6^{+}$ & & 8053 & 9197 & 11564 & 15644 & 17939 & & 22057 & & & & 26 \\
\hline $7^{+}$ & & & & & & & 23450 & 26282 & & & & 4 \\
\hline $\mathrm{N}$ & 59 & 31 & 25 & 21 & 10 & 1 & 2 & 4 & & & & 153 \\
\hline
\end{tabular}

Table 5. Relation between Absolute Fecundity (F) and Relative Fecundity (R.F) with Fork length, Total weight, Net weight and age of roach (Rutilus rutilus) in Lake Volvi

\begin{tabular}{|c|c|c|c|}
\hline Fork length (mm) & $\mathrm{F}=2.9753 \cdot 10^{-4} \mathrm{~L}^{3.47}$ & $R^{2}=0.870$ & $\mathrm{~N}=153$ \\
\hline Total weight (g) & $\mathrm{F}=164.68 \cdot \mathrm{TW}^{1.0310}$ & $R^{2}=0.955$ & $N=153$ \\
\hline “Net” weight (g) & $F=169.86 \cdot N^{1.1001}$ & $R^{2}=0.910$ & $N=153$ \\
\hline Age & $\ln F=6,99+0,4149 \ln (t)$ & $R^{2}=0.980$ & $N=153$ \\
\hline Fork length (mm) & R.F. $=0.155 \cdot I+165.8$ & $R^{2}=0.007$ & $\mathrm{~N}=153$ \\
\hline Total weight (g) & R.F. $=0.097 \cdot T W+182.5$ & $R^{2}=0.004$ & $N=153$ \\
\hline “Net" weight (g) & R.F. $=0.172 \cdot N W+181.3$ & $R^{2}=0.006$ & $N=153$ \\
\hline Age & R.F. $=0.994 \cdot t+182.0$ & $R^{2}=0.000$ & $\mathrm{~N}=153$ \\
\hline
\end{tabular}




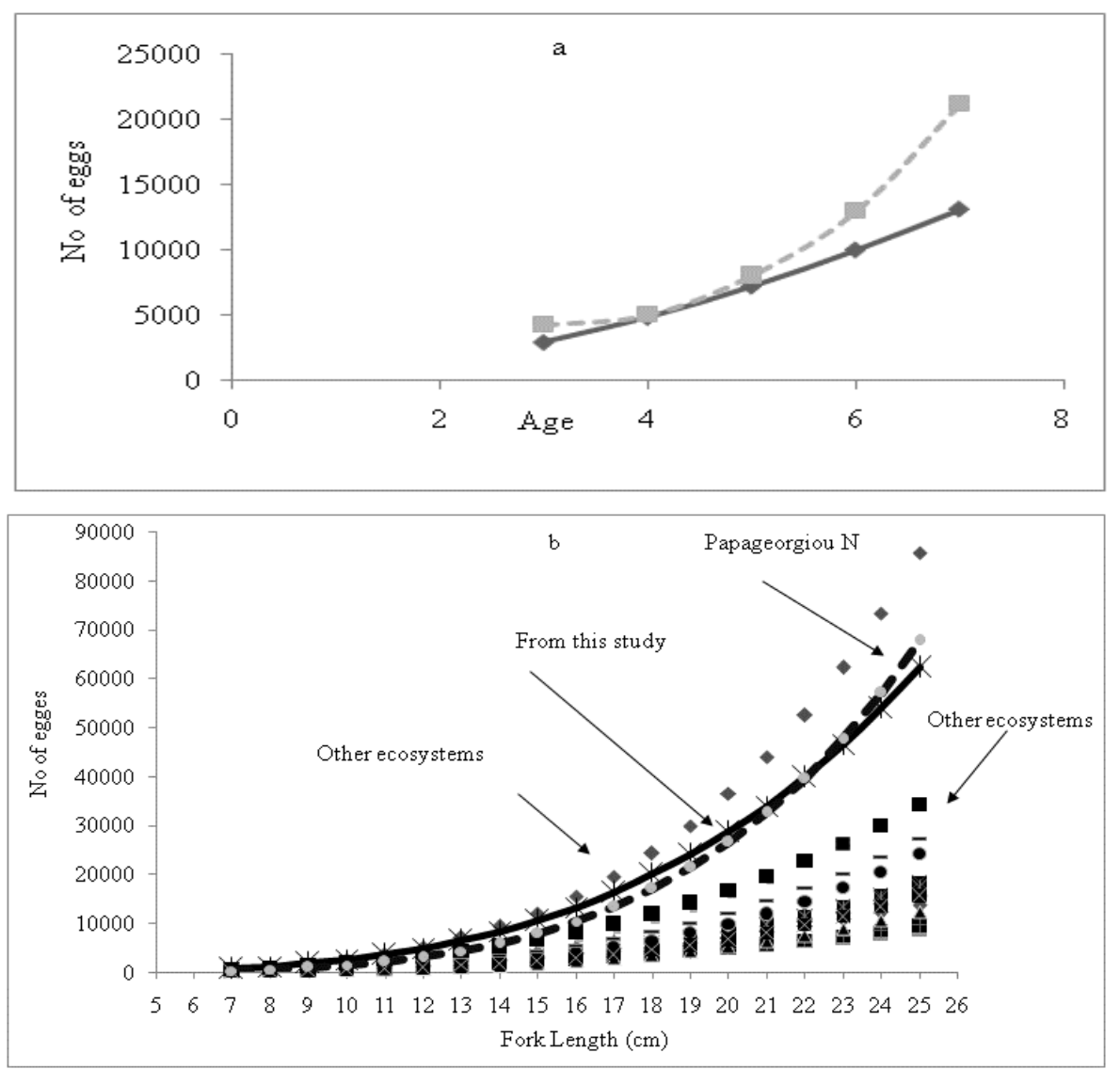

Figure 6. a) Relation between fecundity and age of roach in Lake Volvi $(\mathrm{N}=153)$. Continue line= theoretical curve, Interrupted line= observed curve and $\mathbf{b}$ ) the fecundity of roach in lake Volvi and in other ecosystems.

Table 6. Average absolute and relative fecundity per length class of the spawners roach (Rutilus rutilus) in Lake Volvi

\begin{tabular}{lcccccccccccc}
\hline Length $(\mathrm{mm})$ & \multicolumn{4}{c}{ Absolute fecundity (eggs) } & \multicolumn{3}{c}{ Relative fecundity (eggs) } & \multicolumn{2}{c}{ Number } \\
\hline & Average & \multicolumn{3}{c}{ STDEV } & \multicolumn{2}{c}{ Range } & Average & & STDEV & \multicolumn{2}{c}{ Range } \\
\hline $100-109$ & 3205 & \pm & 776.8 & 2370 & 4540 & 180.34 & 20.00 & 157.26 & 206.95 & 180.34 & 6 \\
$110-119$ & 4135 & \pm & 1069.4 & 2822 & 8249 & 185.58 & 35.29 & 142.33 & 297.78 & 185.58 & 39 \\
$120-129$ & 5187 & \pm & 1716.4 & 2036 & 8096 & 187.86 & 61.56 & 76.06 & 321.20 & 187.86 & 19 \\
$130-139$ & 7464 & \pm & 1093.2 & 6039 & 9973 & 183.59 & 24.59 & 146.35 & 234.22 & 183.59 & 23 \\
$140-149$ & 9595 & \pm & 1444.7 & 6834 & 11877 & 190.80 & 26.03 & 121.62 & 226.97 & 190.80 & 28 \\
$150-159$ & 10514 & \pm & 1938.1 & 7461 & 14105 & 173.66 & 22.72 & 112.86 & 217.30 & 173.66 & 23 \\
$160-169$ & 15945 & \pm & 3416.2 & 11460 & 20851 & 216.83 & 58.68 & 158.09 & 333.94 & 216.83 & 10 \\
$170-179$ & 13962 & & & & & 154.50 & & & & 154.50 & 1 \\
$180-189$ & 22753 & \pm & 985.0 & 22057 & 23450 & 206.99 & 12.36 & 198.25 & 215.73 & 206.99 & 2 \\
$190-199$ & 26282 & & & & & 225.66 & & & & 225.66 & 1 \\
$200-209$ & 31653 & & & & & 190.05 & & & & & & \\
\hline
\end{tabular}

Table 7. Relation of egg diameter $(\mathrm{mm})$ and egg weight $(\mathrm{g})$ with length $(\mathrm{mm})$, age and weight (Total - Net)(g) of roach (Rutilus rutilus) in Lake Volvi

\begin{tabular}{lll}
\hline Egg diameter $=0.0037 \cdot \mathrm{L}+12.346$ & $\mathrm{R}^{2}=0.0188$ & $\mathrm{P}>0.05$ \\
Egg diameter $=0.0891 \cdot \mathrm{t}+12.424$ & $\mathrm{R}^{2}=0.0165$ & $\mathrm{P}>0.05$ \\
Egg diameter $=0.0046 \cdot \mathrm{NW}+12.70$ & $\mathrm{R}^{2}=0.0119$ & $\mathrm{P}>0.05$ \\
Egg diameter $=0.0037 \cdot \mathrm{TW}+12.69$ & $\mathrm{R}^{2}=0.0119$ & $\mathrm{P}>0.05$ \\
Egg weight $=0.0011 \cdot \mathrm{L}+0.9203$ & $\mathrm{R}^{2}=0.0188$ & $\mathrm{P}>0.05$ \\
Egg weight $=0.0213 \cdot \mathrm{t}+0.966$ & $\mathrm{R}^{2}=0.0175$ & $\mathrm{P}>0.05$ \\
Egg weight $=0.0012 \cdot \mathrm{NW}+1.0274$ & $\mathrm{R}^{2}=0.0161$ & $\mathrm{P}>0.05$ \\
Egg weight $=0.001 \cdot \mathrm{TW}+1.0224$ & $\mathrm{R}^{2}=0.0203$ & $\mathrm{P}>0.05$ \\
Egg weight $=1.899 \cdot$ Egg diameter -1.3723 & $\mathrm{R}^{2}=0.6670$ & $\mathrm{P}<0.05$ \\
\hline
\end{tabular}




\section{Discussion}

The growth of roach in Lake Volvi can be characterized as one of the lowest worldwide, where as the onset of maturation occurs at a comparably early age, and fecundity is comparably high. In fact, roach achieves its highest length compared with the reported average $(60 \mathrm{~mm})$ during the first year of its life, whereas after the second year growth rate was highly reduced. The mean weight and growth of the roach is suggested to be highly dependent on lake size, suggesting that the lower abundance of the roach in large lakes is a phenomenon and not related to gear selectivity (Olin, Tiainen, Kurkilahti, Rask, \& Lehtonen, 2016). Intraspecific competition appears to be one of the main factors affecting the growth rate of roach, and the mean weight and growth rate were the lowest in case that abundance was highest (Olin et al., 2016).

Our findings are in agreement with those of other studies, which found that females of roach exhibited higher ultimate length $\left(L_{\infty}\right)$ than males, whereas $L_{\infty}$ values for combined sex were lower than those estimated in other lakes (Caspian lake: Naddafi, Abdoli, Kiabi, Amiri, \& Karami, 2005; and Tavropos Lake: Bobori et al., 2017) (Figure 7). The differences in $L_{\infty}$ values can be explained by the changes of environmental conditions and mainly from temperature. For instance, $L_{\infty}$ increases when the temperature decreases (Basilone, Guisande, Patti, Mazzola, Cuttitta, Bonanno, \& Kallianiotis, 2004).

The value of $W_{\infty}$ for females $(508.618 \mathrm{~g})$ was four times higher than in males $(120.074 \mathrm{~g})$, a fact that is related to the population density (Nikolsly, 1969). The curve of correlation of the total weight with the age for both sexes, showed a superiority of the females in weight after the age of $3+$. The maturity in females compared to the males usually occurs one year later (in the age of 2+) (Mann, 1992). This, combined with the relatively higher mortality rate of males, contributes to the density of the population, thus ensuring large females who usually have higher fecundity for a given amount of food (Nikolsky, 1969).

Early maturity in males in relation to female is a common phenomenon worldwide (Hansen, 1981; Zerunian, Valentini, \& Gibertini, 1986; Stoessel, 2014). The same was also true for the positive correlation between age and geographical latitude (Wootton, 1992). In hot climates many cyprinidae mature in lower age (Rutilus rutilus: Goldspink, 1979; cyprinidae: Mann, 1992; Chalcalburnus chalcoides macedonicus: Kokkinakis, 1992; Abramis brama: Valoukas, 1999). The range of mature for male roach is between 1-4 years and for female 2-5 years (Tarkan, 2006; Stoessel, 2014). Our findings showed that in Lake Volvi, the roach becomes mature in lower age than in other areas, which is in agreement with those referred by the study of Papageorgiou (1979).

Annual ring is formed once a year (May) simultaneously with the start of growing period that can be considered as the month for starting age of roach in Volvi, which is in agreement with Mann, 1973 and Stoessel, 2014, while in other studies annual ring is formatted in June (U.K.: Hellaweell, 1972; Linfield, 1979). This difference in growth can be attributed to temperature due to the positive correlation between $\mathrm{k}$ parameter and water temperature (Pauly, 1980).

The relationship between length and scale radius was found significantly linear, which is similar with other studies conducted worldwide (i.e., Hellawell, 1972; Mann, 1973; Goldspink, 1979; Cowx, 1988; Horppila, 2000).

Reproduction takes place once a year, from the end of March till April following a quick decline in accordance with the estimates provided by Papageorgiou (1979). Roach breeding occurs in a short period (from 1 to 3 months: Vøllestad \& L'Abée-Lund,

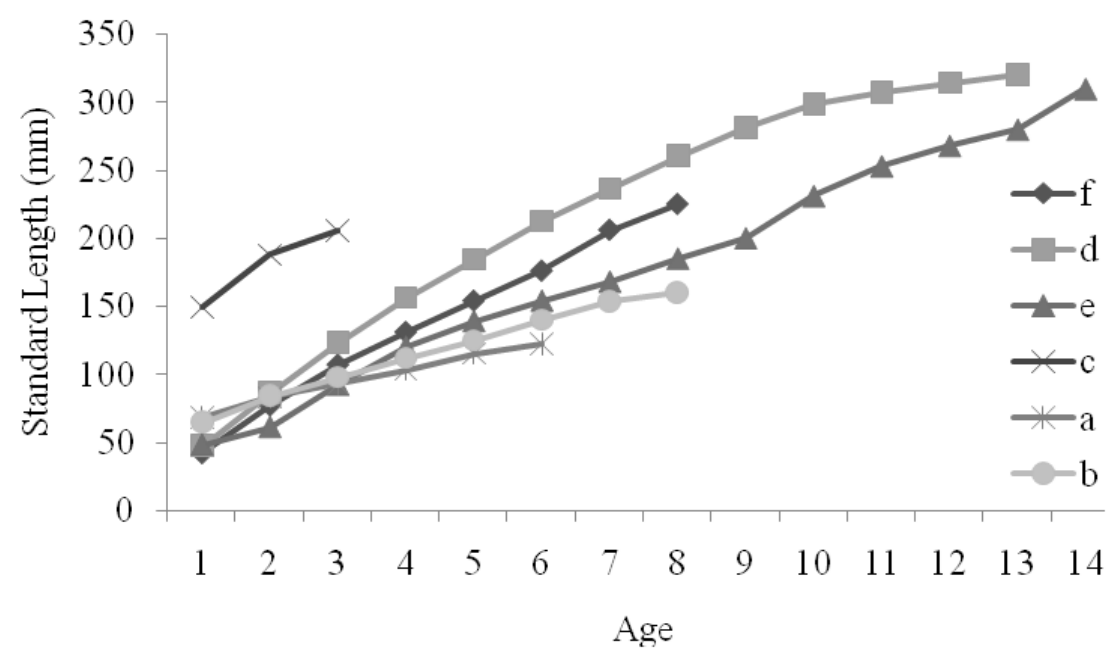

Figure 7. Growth curves of roach from other ecosystems, a) males from Lake Volvi, b) females from Lake Volvi, c) Puiu lake, d) Frome river, e) Rskovsk reservoir and f) Dniepe river 
1987; Tarkan, 2006). On the contrary, when the rate of temperature gradually increases, roach breeding is lasting for a longer period of time. Sexual maturty of roach is delayed when temperature declines with distance from the equator (i.e., Vøllestad \& L'AbéeLund, 1987; Cowx, 1990; Tarkan, 2006; Stoessel, 2014).

Reproductive circle of Cyprinidae in temperate climate countries triggered from external factors such as the photo-period and the temperature (Scott, 1979; Mills, 1992). The beginning of reproduction period for roach within time is not stable. Temperature, rainfall and wind are factors that play an important role in the onset of the breeding period (Diamond, 1985; Vøllestad \& L'Abée-Lund, 1987). During this period the roach move towards the coast where there are the adequate conditions to lay their eggs. However, none of the above factors have been studied herein.

The absolute fecundity of roach increased with increasing length, weight and age a result applied for the great majority of fish species as it is referred by Bagenal (1978). Relative fecundity was found not to be affected from the changes in length, weight (total-net) and age that is observed during the fish growth.

The fecundity of fish of the same length, weight or age fluctuated between relatively wide limits. The relation that connects the age and fecundity was found to be expressed better with the exponential equation also as Mackay and Mann (1969). In the present study, the estimated fecundity was among the highest when compared with that from other ecosystems worldwide (Figure 6b: Mackay \& Mann, 1969; Mann, 1973; Goldspink, 1979; Papageorgiou, 1979; Libosvarsky, Saeed, \& Nemcova, 1985; Vøllestad \& L'Abée-Lund, 1990; Vila-Gispert \& Moreno-Amich, 2000). Bagenal, (1978) showed that between many factors, such as food and density of the population, are playing an important role in fecundity.

The size of the eggs is part of the reproduction strategy of the fish. In many species, it has been observed that there is a relationship between the size of the eggs, the length of female and the temperature (Vøllestad \& L'Abée-Lund, 1987; Wootton, 1992). In the present study, the diameter of the eggs (1.063-1.423 $\mathrm{mm}$ ) was within the range founded by other studies (Naddafi et al., 2005; Tarkan, 2006). Naddafi et al. (2005) compared two different populations of roach and they do not observe any statistical difference in the mean value of egg diameter. The diameter and the weight of eggs were independent from the size of the fish and its age $(P>0.05)$. The only positive correlation was found between the diameter and the weight of the eggs. Vøllestad and L'Abée-Lund, (1990) showed that in 5 out of 7 studied populations there was no correlation between the weight of eggs and the length. However, the length-weight relationship of eggs was statistically different between the populations and in some of them between the year period. It seems that the weight and the diameter of the eggs have been affected by many environmental factors (Vøllestad \& L'Abée-Lund, 1990)

\section{References}

Bagenal, T. B. (1978). Aspects of fish fecundity. S.D. Gerking (Eds.), In Ecology of Freshwater Fish Production (pp. 75101). Blackwell Scientific Publ., Oxford.

Bagenal, T. B. (1978). Fecundity. Bagenal (Eds.), Methods for assessment of fish production in fresh waters (pp. 166178). Blackwell Scientific Publ., Oxford.

Bagenal, T. B., \& Braum, E. (1978). Eggs and Early Life History. T.B. Bagenal (Eds.), Methods for assessment of fish production in fresh waters (pp. 165-201). Blackwell Scientific Publ., Oxford.

Bagenal, T. B., \& Tesch, F.W. (1978). Age and Growth. T.B. Bagenal (Eds.), Methods for assessment of fish production in fresh waters (pp. 101-136). Blackwell Scientific Publ., Oxford.

Barbieri, R., Zogaris, S., Kalogianni, E., Stoumboudi, M. Th., Chatzinikolaou, Y., Giakoumi, S., Kapakos, Y., Kommatas, D., Koutsikos, N., Tachos, V., Vardakas, L., \& Economou, A.N. (2015). Freshwater Fishes and Lampreys of Greece: An annotated checklist. Monographs on Marine Sciences No. 8. Hellenic Centre for Marine Research: Athens, Greece, 62 pp.

Basilone, G., Guisande, C., Patti, B., Mazzola, S., Cuttitta, A., Bonanno, A., \& Kallianiotis, A. (2004). Linking habitat conditions and growth in the European anchovy (Engraulis encrasicolus). Fisheries Research. 68, 9-19. https://doi.org/10.1016/j.fishres.2004.02.012

Bobori, D. C., Moutopoulos, D. K., Bekri, M., Salvarina, I., \& Munoz, I.P. (2010). Length-weight relationships of freshwater fish species caught in three Greek lakes. Journal of Biological Research-Thessaloniki, 14, 219-224.

Bobori, D. C., Kanakis, N. D., Petriki, O., \& Tsikliras, C. A. (2017). Lake Morphometry and Trophic Status Affect Life-history Characteristics of Populations of Rutilus rutilus (L., 1758) (Cyprinidae) in Temperate Lakes. Acta Zoologica Bulgarica, 69(3), 369-376

Cowx, I. G. (1988). Distribution and variation in the growth of roach, Rutilus rutilus (L.), and dace, Leuciscus leuciscus (L.), in a river catchment in south-west England. Journal of Fish Biology, 33(1), 59-72. https://doi.org/10.1111/j.1095-8649.1988.tb05448.x

Cowx, I. G. (1990). The reproductive tactics of roach, Rutilus rutilus (L.) and dace, Leuciscus leuciscus (L.) populations in the Rivers Exe and Culm, England. Polskie Archiwum Hydrobiologii, 37, 193-208.

Diamond, M. (1985). Some observations of spawning by roach, Rutilus rutilus L., and bream, Abramis brama L., and their implications for management. Aquaculture \& Fisheries Management, 16, 359-367. https://doi.org/10.1111/j.1365-2109.1985.tb00078.x

Economidis, P.S., \& Banarescu, P.M. (1991). The distribution and origins of freshwater fishes in the Balkan Peninsula, especially in Greece. International Review of Hydrobiology, 76, 257-283. https://doi.org/10.1002/iroh.19910760209

Economou, A.N., Giakoumi, S., Vardakas, L., Barbieri, R., Stoumboudi, M., \& Zogaris, S. (2007). The freshwater ichthyofauna of Greece - an update based on a hydrographic basin survey. Mediterranean Marine Science 8(1), 91-166.

http://dx.doi.org/10.12681/mms.164

Goldspink, C. R. (1979). The population density, growth rate and production of roach Rutilus rutilus (L.) the 
Netherlands. Journal of Fish Biology, 15, 473-498. https://doi.org/10.1111/j.1095-8649.1979.tb03632.x

Hansen, L. P. (1981). Age, growth and maturity of roach Rutilus rutilus (L.) in Lake Øyeren (in Norwegian with English Summary). Fauna, 34, 20-27.

Hellawell, J. M. (1972). The growth, reproduction and food of the roach Rutilus rutilus (L.), of the River Lugg, Herefordshire. Journal of Fish Biology, 4(4), 469-486. https://doi.org/10.1111/j.1095-8649.1972.tb05696.x

Hilborn, R., \& Walters, J. C. (1992). Quantitative fisheries stock assessment, choice, dynamics \& uncertainty. Chapman and Hall. New York., 570pp

Holden, M. J., \& Raitt, D. F. S. (1974). Manual of fisheries science. Part 2. Methods of resource investigation and their application. F.A.O. Fisheries Technical Paper 115(1), $214 \mathrm{pp}$.

Horppila, J. (2000). The effect of length frequency ranges on the back-calculated lengths of roach, Rutilus rutilus (L.). Fisheries Research, 45, 21-29. https://doi.org/10.1016/S0165-7836(99)00099-5

Kokkinakis, A. K. (1992). Comparative study of the biology and dynamics of the fish Chalcalburnus chalcoides macedonicus Stephanidis, 1971 (Pisces: Cyprinidae) of the systems Volvi and Vistonis (PhD Thesis). AUTH University, Thessaloniki, Greece.

Kottelat, M, \& Freyhof, J. (2007). Handbook of European Freshwater Fishes. Cornol, Switzerland, Publications Kottelat, $646 \mathrm{pp}$.

Lagler, K. F. (1978). Capture, sampling and examination of fishes. In: Bagenal T.B. (Eds.) Methods of assessment of fish production in freshwater (pp. 7-47). Blackwell Scientific Publications, Oxford.

Libosvarsky, V. A., Saeed, D. W., \& Nemcova, M. (1985). Fecundity of roach in a newly built reservoir. Folia Zoologica, 34, 357-372.

Linfield, R. S. J. (1979). Age determination and year class structure in a stunted roach, Rutilus rutilus population. Journal of Fish Biology, 14, 73-87. https://doi.org/10.1111/j.1095-8649.1979.tb03497.x

Mackay, I., \& Mann, R. H. K. (1969). Fecundity of two cyprinid fishes in the river Thames, Reading, England. Journal of the Fisheries Research Board of Canada, 26, 2795-2805. https://doi.org/10.1139/f69-276

Mann, R. H. K. (1973). Observations on the age, growth, reproduction and food of the roach Rutilus rutilus (L.) in two rivers in southern England. Journal of Fish Biology, 5, 707-736.

https://doi.org/10.1111/j.1095-8649.1973.tb04506.x

Mann, R. H. K. (1992). Growth and production. Ian Winfield \& J. Nelson (Eds.), Cyprinid fishes, systematic, biology and exploitation (pp. 456-482). Chapman \& Hall

Mills, C. A. (1992). Reproduction and life history. Ian Winfield \& J. Nelson (Eds.), Cyprinid fishes, systematic, biology and exploitation (pp 426-455). Chapman \& Hall.

Naddafi, R., Abdoli, A., Kiabi, B. H., Amiri, B. M., \& Karami, M. (2005). Age, growth and reproduction of the Caspian roach (Rutilus rutilus caspicus) in thae Anzali and Gomishan wetlands, North Iran. Journal of Applied Ichthyology, 21, 1-6. https://doi.org/10.1111/j.14390426.2005.00669.x
Nikolsky, G. V. (1969). Theory of fish population dynamics as the biological background for rational exploitation and management of fishery resources. Oliver \& Boyd, Edinburgh. (Translation of Nikolsky 1965.) 78pp.

Olin, M., Tiainen, J., Kurkilahti, M., Rask, M., \& Lehtonen, H. (2016). An evaluation of gillnet CPUE as an index of perch density in small forest lakes. Fisheries Research, 173, 2025. https://doi.org/10.1016/j.fishres.2015.05.018

Papageorgiou, N. K. (1979). The length weight relationship, age, growth and reproduction of the roach Rutilus rutilus (L) in Lake Volvi. Journal of Fish Biology, 14, 529-538. https://doi.org/10.1111/j.1095-8649.1979.tb03552.x

Pauly, D. (1980). On the interrelationships between natural mortality, growth parameters and mean environmental temperature in 175 fish stocks. Journal of Marine Science, 39(2), 175-192. https://doi.org/10.1093/icesjms/39.2.175

Scott, D. B. C. (1979). Environmental timing and the control of reproduction in teleost fish. Symposia of the Zoological Society of London, 44, 105-132.

Staras, M., Cernisencu, I., \& Navodaru, I. (1995) Studiul cresterii principalelor specii de pesti din complexul Razim-Sinoe. Aquaropi, Galaxi, Romania, 417-420

Stoessel, J. D. (2014). Age, growth, condition and reproduction of roach Rutilus rutilus (Teleostei: Cyprinidae), in southeastern Australia. Marine and Freshwater Research, 65, 275-281. https://doi.org/10.1071/MF13095

Tarkan, A. S. (2006). Reproductive ecology of two cyprinid fishes in an oligotrophic lake near the southern limits of their distribution range. Ecology of Freshwater Fish, 15(2), 131-138. https://doi.org/10.1111/j.1600-0633.2006.00133.x

Valoukas, B. A. (1999). Biology and population dynamics of the bream Abramis brama (Pisces. Cyprinidae) in Lake Volvi (PhD Thesis). AUTH University, Thessaloniki, Greece.

Vila-Gispert, A., \& Moreno-Amich, R. (2000). Fecundity and spawning mode of three introduced fish species in Lake Banyoles (Catalunya, Spain) in comparison with other localities. Aquatic Sciences, 61, 154-166. https://doi.org/10.1007/s000270050004

Vøllestad, L. A., \& L'Abée-Lund, J.H. (1987). Reproductive biology of stream-spawning roach, Rutilus rutilus. Environmental Biology of Fishes, 18, 219-227. https://doi.org/10.1007/BF00000361

Vøllestad, L. A., \& L'Abée-Lund, J.H. (1990). Geographic variation in life-history strategy of female roach, Rutilus rutilus (L.). Journal of Fish Biology, 37(6), 853-864. https://doi.org/10.1111/j.1095-8649.1990.tb03589.x

Wootton, R. J. (1992). Fish Ecology. Chapman and Hall, New York, 25-131 pp

Zerunian, S., Valentini, L., \& Gibertini, G. (1986). Growth and reproduction of rudd and red-eye roach (Pisces, Cyprinidae) in Lake Bracciano. Journal Bollettino di zoologia, 53, 91-95. https://doi.org/10.1080/11250008609355489

Zivkov, M., \& Raikova-Petrova, G. (2001). Comparative analysis of age composition, growth rate and condition of roach, Rutilus rutilus (L.) in three bulgarian reservoirs. Acta Zoologica Bulgarica, 53(1): 47-60 